\title{
Stakeholders' Opinions towards Water-Related Forests Ecosystem Services in Selected Southeast European Countries (Federation of Bosnia and Herzegovina, Croatia, Slovenia and Serbia)
}

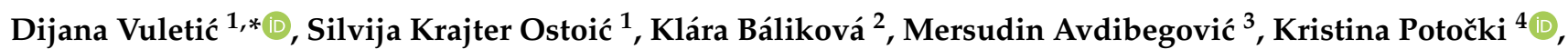 \\ Špela Pezdevšek Malovrh ${ }^{5}$, Stjepan Posavec ${ }^{6}$, Srđan Stojnić ${ }^{7}{ }^{(1)}$ and Alessandro Paletto ${ }^{8}$ (i)
}

check for updates

Citation: Vuletić, D.; Ostoić, S.K.; Báliková, K.; Avdibegović, M.; Potočki, K.; Pezdevšek Malovrh, Š.; Posavec, S.; Stojnić, S.; Paletto, A. Stakeholders' Opinions towards Water-Related Forests Ecosystem Services in Selected Southeast European Countries (Federation of Bosnia and Herzegovina, Croatia, Slovenia and Serbia). Sustainability 2021, 13, 12001. https://doi.org/ $10.3390 /$ su132112001

Academic Editor: Stephen Morse

Received: 17 September 2021

Accepted: 26 October 2021

Published: 29 October 2021

Publisher's Note: MDPI stays neutral with regard to jurisdictional claims in published maps and institutional affiliations.

Copyright: (C) 2021 by the authors. Licensee MDPI, Basel, Switzerland. This article is an open access article distributed under the terms and conditions of the Creative Commons Attribution (CC BY) license (https:// creativecommons.org/licenses/by/ $4.0 /)$.
1 Division for International Scientific Cooperation in Southeast Europe (EFISEE), Croatian Forest Research Institute, 10450 Jastrebarsko, Croatia; silvijak@sumins.hr

2 Department of Forest Economics and Management, Faculty of Forestry, Technical University in Zvolen, 96001 Zvolen, Slovakia; klara.balikova@tuzvo.sk

3 Faculty of Forestry, University of Sarajevo, Zagrebačka 20, 71000 Sarajevo, Bosnia and Herzegovina; mavdibegovic@gmail.com

4 Water Research Department, Faculty of Civil Engineering, University of Zagreb, 10000 Zagreb, Croatia; kpotocki@grad.hr

5 Department of Forestry and Renewable Forest Resources, Biotechnical Faculty, University of Ljubljana, 1000 Ljubljana, Slovenia; Spela.PezdevsekMalovrh@bf.uni-lj.si

6 Faculty of Forestry and Wood Technology, University of Zagreb, Svetošimunska cesta 25, 10000 Zagreb, Croatia; sposavec@sumfak.hr

7 Institute of Lowland Forestry and Environment, University of Novi Sad, 381021 Novi Sad, Serbia; srdjan.stojnic@uns.ac.rs

8 Consiglio Per La Ricerca in Agricoltura E L'analisi dell'economia agraria (CREA), Forestry and Wood Research Centre, 38123 Trento, Italy; alessandro.paletto@crea.gov.it

* Correspondence: dijanav@sumins.hr; Tel.: +385-98-324-226

Abstract: Even though water-related forest ecosystem services are important for forestry and water management sectors, they have different definitions and are regulated differently in each sector, which makes them poorly recognized. How stakeholders from two main sectors (forestry and water management) perceive the importance of water-related forest ecosystem services, the trade-offs between ecosystem services and the effectiveness and implementation of payments schemes related to forest water ecosystem services were our areas of interest. We have conduct surveys with different groups of stakeholders from both sectors in four selected countries (the Federation of Bosnia and Herzegovina, Croatia, Slovenia and Serbia) with a lot of similarities and the potential to learn from each other. The results show that in spite of the spotted differences among analyzed countries, there is a high level of agreement among respondents on all investigated aspects. In addition, even though different payment schemes exist in three of four countries, stakeholders are rarely aware of their existence, or it is better to say that they do not recognize them as payment schemes for ecosystem services because of their names and definitions, which do not clearly define ecosystem services. Mostly, they use bundled services and non-voluntary payments and are designed and implemented by the states. Due to the strong role of states and the low transparency in the existing schemes, we looked at possible conditions reflected through stakeholders' opinions for overcoming that obstacle for the development of new payment schemes. We found that there is a high level of acceptance of payments schemes as more effective than "command and control" schemes and of the involvement of other stakeholders in decision-making processes as those conditions that can positively influence development of new payment schemes in all four countries. These results give us hope that in spite of the strong role of the state in selected countries, the role of stakeholders will be more acknowledged and, by that, the future schemes will be more harmonized among the sectors and their goals and needs, contributing to its effectiveness as well.

Keywords: water-related ecosystem services (WES); stakeholder analysis; questionnaire survey; payments for ecosystem services (PES) 


\section{Introduction}

Forests, as ecosystems, provide a range of benefits to people [1-3] of which waterrelated ecosystem services (WES) are considered critical to human well-being [4,5]. A clean and reliable drinking water supply is one of the most important benefits of well-managed forests. Other services provided by forests include the regulation of groundwater and surface water flow, water purification, the control of runoff and erosion from heavy rainfall, evapotranspiration, infiltration and groundwater recharge and runoff into streams [6,7]. The WES are classified in different classification schemes (Millennium Ecosystem Assessment (MEA), the Economics of Ecosystems and Biodiversity (TEEB) or the Common International Classification of Ecosystem Services (CICES)), partly as provision and partly as regulating ecosystem services (ES) [8-10].

Many recent studies have highlighted the role of forest management and mismanagement in influencing hydrological cycles and outcomes [6,11]. Sustainable forest management is recognized by the scientific community as one of the key elements in providing WES [12-14]. So, we can say that forests, at least in temperate climates, are the best land cover if we want to maximize water yield, regulate seasonal water flows and ensure high water quality [15].

In addition, many policy documents related to forest management (Warsaw Resolution on "Forests and Water", 2007; European Union (EU) Forest Strategy, 2013; and Common Agricultural Policy (CAP)) emphasize the relationship between forests and WES supply [7]. Accordingly, EU member states should ensure soil protection, water quality and water quantity regulation by integrating sustainable forestry practices into the Programme of Measures of River Basin Management Plans (Water Framework Directive, 2000/60/EC) and in the Rural Development Programmes (2014-2020) [16].

However, apart from policy and institutional frameworks, the successful involvement of WES in forest management decisions is very difficult without a broad dialogue with stakeholders [17-19]. Stakeholder engagement can support the dissemination of best practices for maintaining and improving of the provision of WES in forest management, as well as its financing. Payments for Ecosystem Services (PES) are one of the market-based mechanisms that aim to influence decision making about forest management, which is crucial for the sustainable provision of WES [20], and provide financial support. The role of stakeholders in the implementation of PES is very important, and their involvement can be challenging as there are many of them, whom all have different knowledges, interests, needs and perceptions of the current state of ecosystem services (ES) $[16,19,21,22]$. Stakeholders may be individuals, groups and institutions/organizations from the market, education, research, resource management or government and civil society sectors, each representing different interests and holding different values, thus influencing the implementation of PES [19,23]. PES is not only developed in a particular environmental, economic, social and political context [23] but is also influenced by factors related to the topography, hydrology and demography of the country, where the relationships between WES users and providers, the rugged topography and flooding argue for PES as a solution to water-related problems [24,25].

In this paper, we explored the stakeholders' opinions about the importance of forests' WES, the trade-offs between ES, the environmental effectiveness of PES, the level of stakeholder participation and the key issues related to the development of PES in four selected countries (the Federation of Bosnia and Herzegovina, Croatia, Serbia and Slovenia). The reasons for selecting these countries, are the continuation of research related to PES in these countries $[19,26]$ and primarily, similar conditions that these countries share from a historical, political, social and resource-economic perspective [27]. The potential that PES schemes could provide for better financing of WES provision were additional reasons. All four countries can be considered to be rich with forests, and forestry and water manage- 
ment sectors play important roles in their national economies; however, both sectors are highly controlled by the states, which lead to unfulfilling of their whole potential.

In addition, payments for WES are rarely investigated in these countries [26,28-30], and the experiences and tangible results from member countries (Slovenia and Croatia) can be valuable resources and references for countries in the process of joining the EU (the Federation of Bosnia and Herzegovina and Serbia) [31]. Many researches [32-34] emphasized the role of stakeholders in the possible improvement of policies and the implementation of the various strategies where we see huge potential in development of new PES schemes which will be more effective and much more easily endorsed by the payers if developed together with stakeholders and with cooperation between two respective sectors [35-37].

The main aim of this study is to explore stakeholders' perception of connections between those sectors, dealing with two inseparable resources, through their understanding of the WES. How do they see the effectiveness of PES schemes and are they open for the involvement of different stakeholder groups into the decision-making process, so far reserved only for them? The results will add to the understanding of needed changes that could lead to improvement of existing and opening the space for development of new PES schemes in studied countries.

\section{Materials and Methods}

\subsection{Survey Design and Data Collection}

The study is developed in the context of COST Action CA15206-PESFOR-W (Forests for Water) aimed to consolidate learning from existing forests for water PES schemes in Europe and help standardize their approaches to evaluating the environmental effectiveness and cost-effectiveness of forestry measures. The stakeholder opinions were investigated using a structured questionnaire administrated online in the period from March-July and September-November 2020.

The study was divided into the following steps: (1) stakeholder analysis with the aim of identifying main stakeholders from each sector to be included in the survey for each country; (2) pre-testing of the questionnaire; (3) launching of the online survey and sending the invitations to selected stakeholders, data collection; (4) data processing, analysis and interpretation.

In the first step, a stakeholder analysis was conducted in the forestry and water management sectors as an approach to gain knowledge about stakeholders in order to understand their responsibilities, relations and interests $[16,38]$. The respondents in each country have been identified considering their affiliation to institutions responsible for forest and water management and relevant expertise. Subsequently, all identified stakeholders were contacted by email or phone to invite them to participate in the survey. The preliminary database of stakeholders was supplemented through a snowballing process that included additional stakeholders mentioned by respondents during the administration of the questionnaire.

In the second step, the semi-structured questionnaire was pre-tested by two selected stakeholders from Croatia to understand the ease of completing the questionnaire and the clarity of the proposed questions. At the end of the pre-testing phase, some questions were modified and simplified in accordance with the suggestions and comments of the stakeholders. The final version of the questionnaire consisted of 20 questions, divided into four sections: Section 1 "General and personal information"; Section 2 "Relationship between forests and water"; Section 3 "Payment schemes for Ecosystem Services (PES)"; Section 4 "Stakeholder participation in PES schemes".

The first section of the questionnaire consists of four open-ended questions- "Name of your organization" (Q1.1), "Region/Country" (Q1.2), "Role of the respondent in his/her organization" (Q1.3), "Scientific field of the respondent" (Q1.4)—and one closed-ended question - "Years of activity in the field" (Q1.5)—using the following time classes: less than 1 year; $1-5$ years; 6-10 years; $11-15$ years and more than 15 years. 
The second section consists of four questions on the relationships between forests and water resources. The first question (Q2.1) examines the importance of forests in providing the WES, which are divided into four categories of ecosystem services [39]:

- Provisioning services: recharge of groundwater; provision of clean drinking water;

- Regulating services: buffering and filtering of pollutants; reducing surface runoff; reducing soil erosion; protecting against flood risks;

- Supporting services: Providing habitat for various spices; Maintaining genetic diversity in aquatic ecosystem;

- Cultural services: providing forests and water bodies for recreation and leisure activities; providing scenic beauty of forests and water bodies.

Respondents rated the importance of each WES using a 5-point Likert scale (from $1=$ very low importance to $5=$ very high importance). For the second question (Q2.2), respondents compared the importance of each category of ecosystem services using a pairwise comparison. The last two questions (Q2.3 and Q2.4) address stakeholders' perceptions of trade-offs between WES related to forest management (final logging and thinning) and afforestation/reforestation activities.

The third section deals with the implementation of the PES in the countries studied. In the first question (Q3.1), respondents compared the effectiveness of the PES schemes with the use of regulatory policy instruments (i.e., "command and control" policies). The second question (Q3.2) addresses the degree of importance of three aspects related to the implementation of PES, as follows [18]: (1) Multi-level governance (incorporating local and indigenous knowledge of ecosystem services and payment mechanisms into the decision-making process); (2) shared values for ecosystem services (understanding the ecological and ethical values that can be shared by different groups within society in relation to the natural environment); and (3) bundling or layering of services at different levels (considering the trade-offs between forest ecosystem services). The third question (Q3.3) explores respondents' views on the ecological effectiveness of PES, defined as the change in provision of services included in the program compared to the provision of ES without the PES schemes [37]. The transaction and implementation costs and the direct and indirect effects serve as factors in determining the environmental effectiveness of the PES schemes. In addition, for this question, respondents indicated their preferences on a 5-point Likert scale for Q3.2 and Q3.3 (from 1 = very low importance to $5=$ very high importance). The final question (Q 3.4) in this section maps stakeholders' knowledge of active payments for WES in each country.

The fourth section looks at respondents' opinions on stakeholder participation in PES schemes. The first question (Q4.1) refers to the role of the public sector, distinguishing between four possible roles in the design and development of PES. According to Leonardi and Pettenella $[4,39,40]$, the public sector can act both as a buyer and/or as a legal institution that provides rules and obligations for the design and development of PES. In this study, the following governance models were examined in relation to the role of the public sector: (1) managing payments of WES without any public sector intervention; (2) public sector involvement as buyer; (3) public sector involvement as regulator; and (4) public sector involvement as both buyer and regulator. The first option is based on the Coasean approach, where contracts are negotiated by two private actors without interference from the public sector [41]. Conversely, the participation of the public sector as a buyer in PES schemes is in line with Pigouvian approach [42], where public actors (e.g., municipalities) pay landowners-farmers and forest owners - to improve water quality in water abstraction areas [39]. The second question (Q4.2) refers to the level of involvement of other stakeholders-individual farmers and forest owners, environmental NGOs, tourism associations, farmers' / forest owners' associations, fishing associations, citizens-in the design and development of the PES schemes. Respondents assigned the appropriate level of participation to each stakeholder of a five-point Likert scale: 1 -non-involvement; 2-information; 3-consultation; 4-collaboration/deliberation and 5-co-decision/coproduction. The main characteristics of the four levels of participation are an increasing 
power in the hands of stakeholders and a simultaneous decrease in the number of stakeholders involved due to the necessary expenditure of tangible and non-tangible resources.

\subsection{Data Analysis}

In this step, we investigated the differences or agreement between the four selected countries. Data analyses were performed in period from December 2020 to February 2021. The answers collected in the closed-ended questions were analysed by descriptive statistical methods providing the frequency distribution, mean, median and standard deviation.

For the determination of the hierarchical position of WES within the four categories of ecosystem services (provisioning, regulating, supporting and cultural services), the data collected with question Q2.2 were processed using the Analytic Hierarchy Process (AHP) method. The AHP method is a multi-criteria decision making method used to compare alternatives considering the importance of different criteria to facilitate decisionmaking in complex decision choices $[43,44]$. In this study, the factor priority score $(\mathrm{w})$-a normalized eigenvector of the comparison matrix-defines a ranking of the categories of ES. Within the categories of ES, the relative importance of each WES is calculated as the mean value (data were collected on a 5 -point Likert scale from $1=$ very low importance to $5=$ very high importance). The $\mathrm{CI}$ (consistency index) and CR (consistency ratio) were used to measure how consistent the judgments have been relative to large samples of purely random judgments.

The Shapiro-Wilk test $(\alpha=0.01)$ - designed to compare the similarity between the observed and normal data distributions-shows a non-normal distribution of the data. Therefore, the Kruskal-Wallis test $(\alpha=0.01)$-a non-parametric statistical test to assess differences between three or more independently selected groups on a single, non-normally distributed continuous variable-was used to highlight differences between the four countries, respondents' perception of WES importance and aspects of PES implementation.

The last Q2.3 and Q2.4 were processed in linguistic expression. The answers were checked for keywords referring to the WES categories and used to identify trade-offs related to forest management, reforestation and afforestation.

In the third thematic section, the perceived efficiency of the PES schemes versus regulatory policy instruments, to enhance a forest-related WES along the symmetric Likert scale, was calculated. The average importance levels for the implementation aspects: (1) multilevel governance, (2) shared values for ES, and (3) bundling of layering of services across multiple scales were also calculated.

Data on the role of the public authorities and stakeholders' involvement collected with a multi-answer question were the number of variables corresponded to the maximum number of selected options. The respondents' answers were elaborated through the simple frequency distribution. For statistical data processing, XLStat 2017 software was used.

\section{Results}

At the end of the data collection, 131 stakeholders participated in the survey. The respondents were distributed by countries as follows: 29 from the Federation of Bosnia and Herzegovina (22.1\% of the total), 38 from Croatia (29.0\%), 28 from Serbia (21.4\%) and 36 from Slovenia (27.5\%). Taking into account the number of institutions in each country and the available number of stakeholders, we consider this sample sufficient, as it covers the existing range of opinions towards WES among the stakeholders from both sectors, and it allowed us to execute proper data analysis.

\subsection{Stakeholders' Characteristics}

The selected stakeholders from two sectors (forestry and water management) came from all main institutions responsible (state companies, ministries and chambers), from higher education and research and from nature protection and NGOs active in those sectors, which was reflected in the sample. 
Most of the respondents have expertise in forestry (57.3\%), followed by economics, biology, agriculture, geography, nature and environment protection, civil engineering, and water resource management (the remaining $42.7 \%$ ). The distribution of respondents by country and field of expertise is as follows: $70.0 \%$ forestry and $30.0 \%$ non-forestry in the Federation of Bosnia and Herzegovina; $47.4 \%$ forestry and $52.6 \%$ non-forestry in Croatia; $50.0 \%$ forestry and $50.0 \%$ non-forestry in Serbia; and $61.1 \%$ forestry and $38.9 \%$ non-forestry in Slovenia.

The observed sample of stakeholders is, by years of experience, distributed in five groups: with more than 15 years of experience-37.4\%; with $11-15$ years- $18.3 \%$; with 6-10 years-22.1\%; with $1-5$ years-17.6\%; and the remaining $4.6 \%$ with less than 1 year of experience. The results show that most respondents with more than 15 years of experience come from the Federation of Bosnia and Herzegovina (72.4\%) and Croatia (47.4\%), while in Serbia, the majority of respondents have between 1 and 5 years of experience (39.3\%) and, in Slovenia, between 6 and 10 years of experience $(27.8 \%)$.

\subsection{Water-Related Ecosystem Services}

The results show that, for most stakeholders, the most important category of WES is regulating services $(w=0.3202)$, followed by provisioning services $(w=0.3064)$ and supporting services $(w=0.2209)$. Cultural services, on the other hand, are of low importance compared to the other three categories $(\mathrm{w}=0.1524)($ Table 1$)$.

Table 1. Priority scores (w) for the categories of ecosystem services by country (in bold the highest priority score for ecosystem service category by country).

\begin{tabular}{cccccc}
\hline Category/Priority Score & $\begin{array}{c}\text { Federation of Bosnia and } \\
\text { Herzegovina }(\boldsymbol{n = 2 9 )}\end{array}$ & $\begin{array}{c}\text { Croatia } \\
(\boldsymbol{n}=\mathbf{3 8})\end{array}$ & $\begin{array}{c}\text { Serbia } \\
(\boldsymbol{n}=\mathbf{2 8})\end{array}$ & $\begin{array}{c}\text { Slovenia } \\
(\boldsymbol{n}=\mathbf{3 6})\end{array}$ & $\begin{array}{c}\text { Total } \\
(\boldsymbol{n}=\mathbf{1 3 1})\end{array}$ \\
\hline Provisioning services & $\mathbf{0 . 3 3 0 8}$ & 0.3127 & 0.2750 & 0.3042 & 0.3064 \\
Regulating services & 0.3067 & $\mathbf{0 . 3 3 1 3}$ & $\mathbf{0 . 3 1 2 4}$ & $\mathbf{0 . 3 2 3 3}$ & 0.3202 \\
Supporting services & 0.1984 & 0.2086 & 0.2374 & 0.2401 & 0.2209 \\
Cultural services & 0.1641 & 0.1475 & 0.1752 & 0.1324 & 0.1524 \\
CI & 0.0022 & 0.0029 & 0.0116 & 0.0029 & 0.0031 \\
CR & 0.0024 & 0.0032 & 0.0129 & 0.0033 & 0.0034 \\
\hline
\end{tabular}

$\mathrm{CI}=$ consistency index $\mathrm{CR}=$ consistency ratio.

Looking at the data by county, the results show that for the stakeholders of the Federation of Bosnia and Herzegovina, the most important category is provisioning services, followed by regulating services. For the stakeholders of the other three countries, on the other hand, the most important category is regulating services, followed by provisioning services. It is also interesting to note that stakeholders from the Federation of Bosnia and Herzegovina and Serbia placed a higher value on cultural services than those from Croatia and Slovenia. For all groups of stakeholders, the consistency ratio (CR) is less than $0.05(5 \%)$.

The four most important WES provided by forests are as follows: soil erosion reduction (mean value of 4.65), surface runoff reduction (4.54), clean drinking water provision (4.50) and habitat provision (4.50). Conversely, the two least important ecosystem services according to stakeholders are recreational opportunities (3.92) and maintaining genetic diversity (3.93) (Figure 1). 


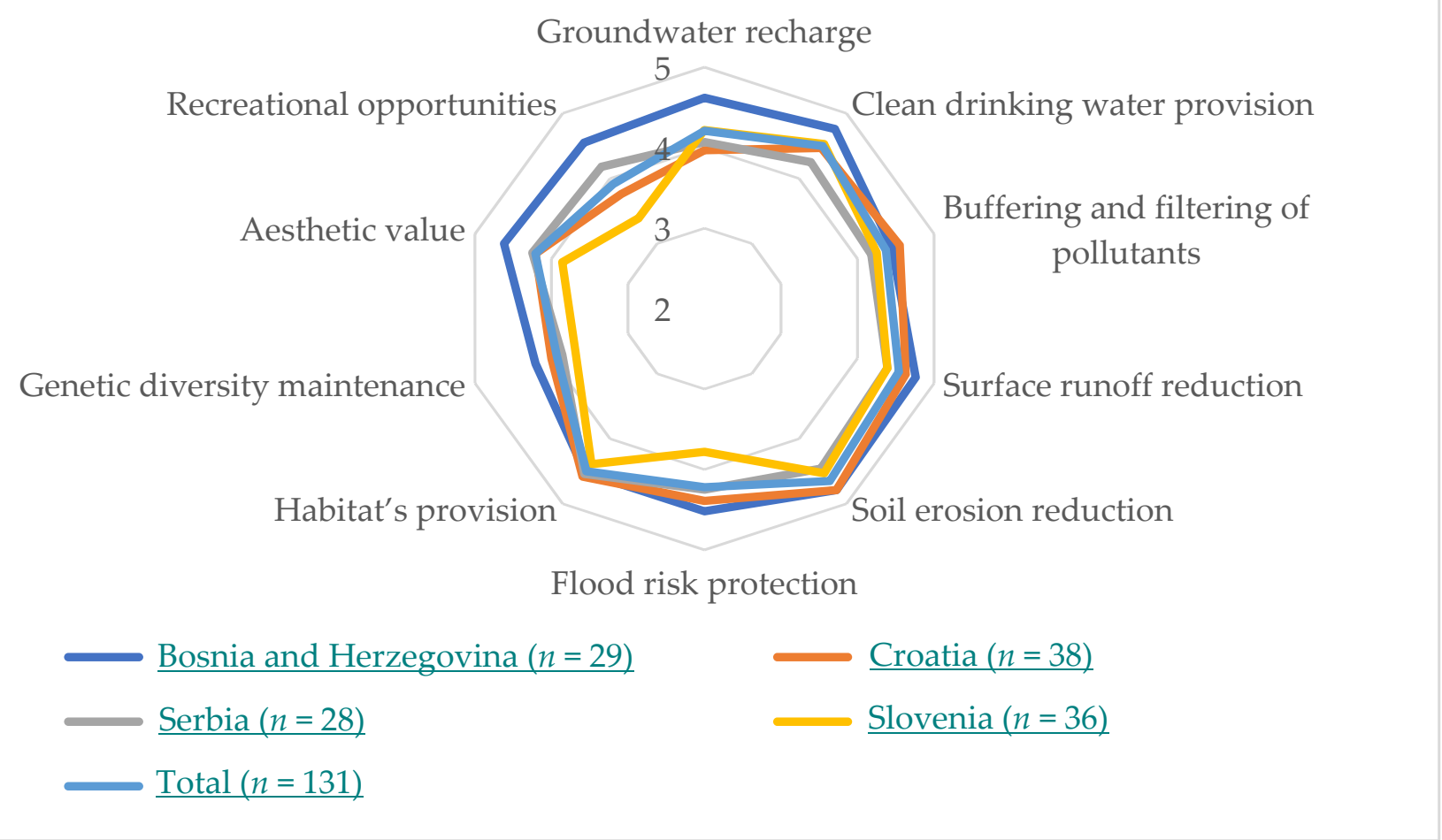

Figure 1. Mean values of importance of ecosystem services by country.

Comparing the data by country, the results show that in three countries the most important ecosystem service is soil erosion reduction (mean of 4.79 in the Federation of Bosnia and Herzegovina and Croatia, 4.53 in Slovenia), while for Serbian stakeholders, the most important ecosystem service is habitat provision (4.54).

The Kruskal-Wallis non-parametric test $(\alpha=0.01)$ shows statistically significant differences between four countries for the following ecosystem services: flood risk reduction $(p=0.002)$ and recreational opportunities $(p<0.0001)$. Regarding flood risk reduction, Slovenian stakeholders attribute less importance to this ecosystem service (mean of 3.78) than the other three countries ( 4.52 for the Federation of Bosnia and Herzegovina, 4.39 for Croatia, 4.25 for Serbia). Instead, recreational opportunities are an important ecosystem services for stakeholders in the Federation of Bosnia and Herzegovina (4.55) and Serbia (4.18), while stakeholders in Croatia (3.76) and Slovenia (3.39) placed lower values on this cultural service.

When analysing the respondents' opinions on the trade-offs between ecosystems services, the results show that forest management activities can lead to potential trade-offs in accordance with the opinions of $70.2 \%$ of all respondents, while afforestation/reforestation activities can lead to trade-offs for $66.4 \%$ of all respondents. For respondents from Croatia, Serbia and Slovenia, both activities can lead to trade-offs between ecosystem services (from a maximum of $80.0 \%$ of Serbian respondents for afforestation/reforestation activities to a minimum of $62.5 \%$ of Croatian respondents for forest management activities). In contrast, for most respondents from the Federation of Bosnia and Herzegovina, afforestation/reforestation activities cannot cause trade-offs between ecosystem services (51.7\%) (Figure 2). However, chi-square tests $(\chi 2)$ show no statistically significant differences among the four countries for either activity: forest management $(\alpha=0.01, p=0.513)$ and afforestation $/$ reforestation $(\alpha=0.01, p=0.076)$. 


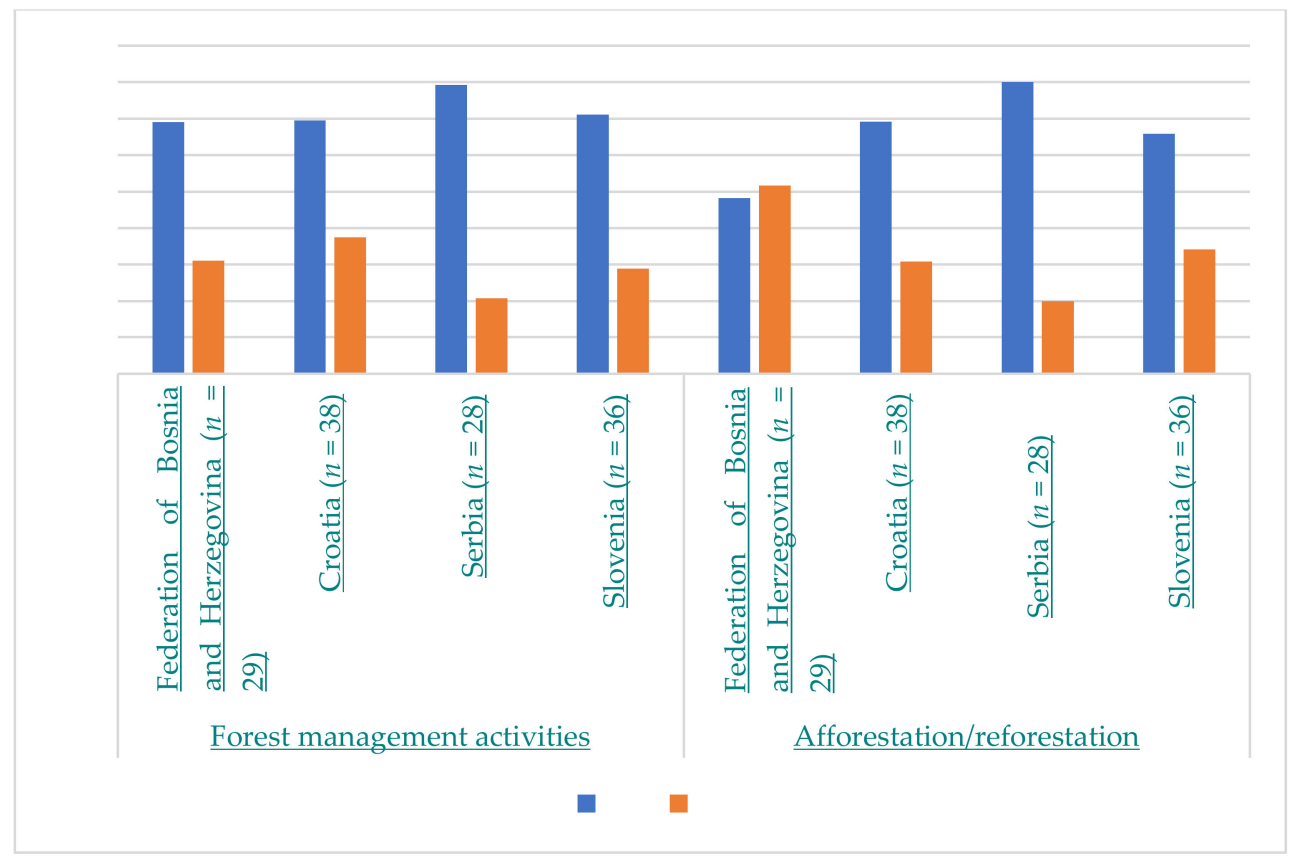

Figure 2. Ratio of positive and negative respondents' opinions towards trade-offs between ecosystem services by country.

\subsection{Stakeholder's Perception towards PES Schemes}

The results of the third section of the questionnaire show a slight prevalence of the effective protection of the providing WES to PES schemes (39.5\%) over the "command and control" instruments ( $36.3 \%$ ), while $24.2 \%$ of the respondents see no difference between the two instruments. Looking at the data by country, the differences between the instruments become more apparent. A higher percentage of respondents (62.1\%) consider PES more efficient than the "command and control" instruments in the Federation of Bosnia and Herzegovina, while the situation in the other three countries is as follows: Croatia$38.2 \%$; Serbia-39.3\%; and Slovenia-45.5\%. However, the chi-square $(\chi 2)$ test shows no statistically significant differences between the countries $(\alpha=0.01, p=0.060)$.

Most respondents are not aware of active PES or PES-like programs in their countries $(74.8 \%)$. From the perspective of respondents in each country, five stakeholders from the Federation of Bosnia and Herzegovina mentioned active PES examples- "Fund for environmental protection of the Republic of Srpska (a part of the Federation of Bosnia and Herzegovina)" and "OKFك̌" payment for Common Forest Ecosystem Services. Almost half of Croatian respondents (17 out of 38) know about active PES schemes, specifically "green taxes" and "OKFك̌" payments. Croatian respondents also mentioned two local PES examples: "Sincere" (Spurring INnovations for Forest Ecosystems SERvices in Europe) and "Mapping and assessment of ecosystems and their services in Croatia". In Slovenia, a lower percentage of respondents $(27.8 \%)$ know of active PES programs in their country such as NATURA 2000 payments, land use change compensation payments and various payments related to forest management practices. In contrast, only one respondent from Serbia gave an example of a local PES-like scheme focused on recreation services.

The analysis of respondents' opinions on the importance of several key aspects related to the implementation of PES (Figure 3) shows that societal actors share a common value for ecosystem services (mean of 4.00) to incorporate local knowledge into the decisionmaking process (3.97). However, in two countries (Federation of Bosnia \& Herzegovina and Croatia), respondents consider multi-level governance that aims to include local knowledge in the decision-making process to be more important (mean of 4.28 and 4.11 respectively), while respondents in Serbia and Slovenia place a higher importance on a shared value for ecosystem services among societal actors (mean of 4.11 for both countries). However, the 
non-parametric Kruskal-Wallis test shows no statistically significant differences between the four countries for all three aspects included in the survey.

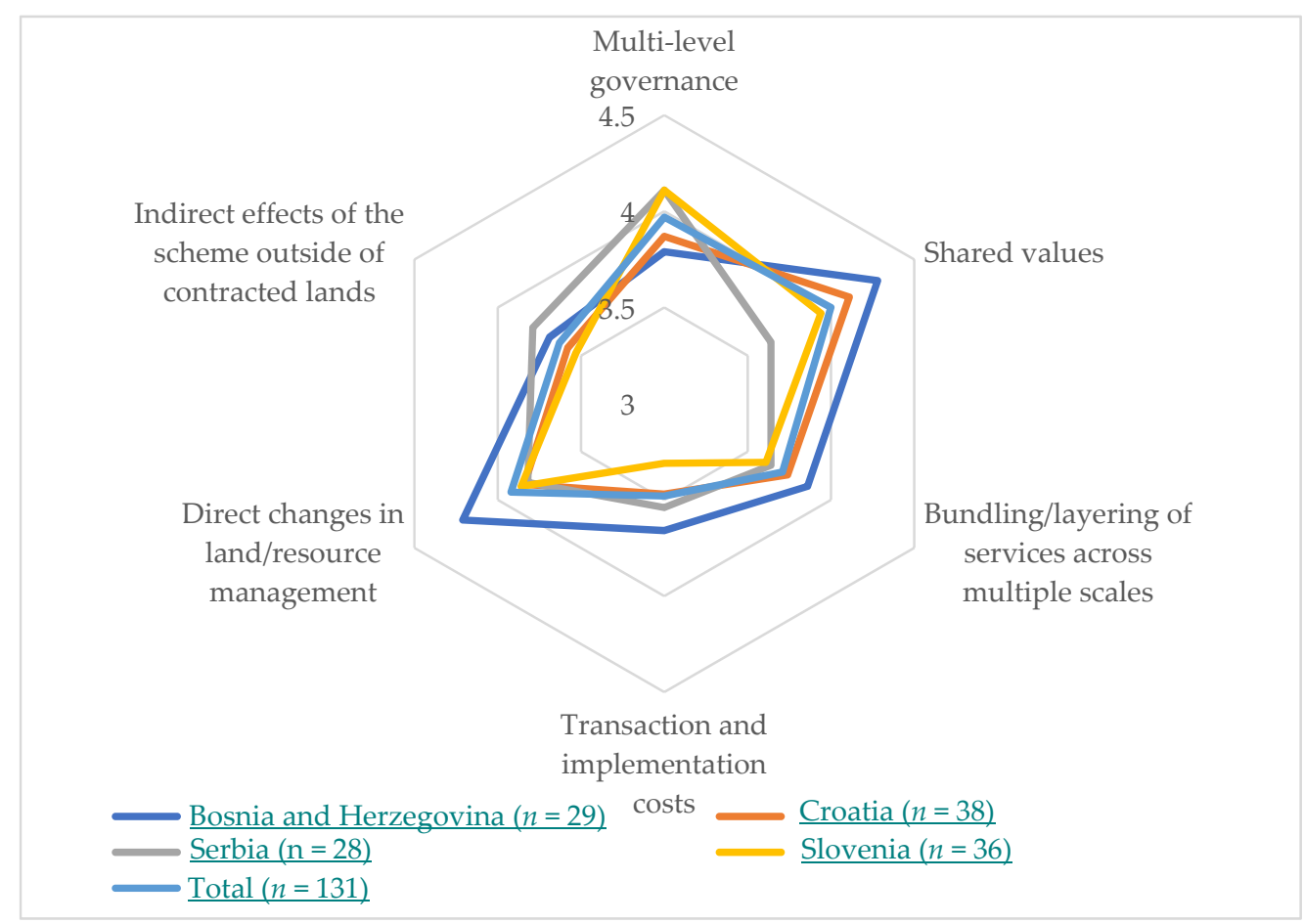

Figure 3. Mean values or importance of key aspects related to the implementation of the PES schemes by country.

Regarding the factors related to the environmental effectiveness of PES, the results show that the most important factor is the direct changes in land/resource management (mean of 3.92), followed by the indirect effects of the scheme outside the contract areas (3.63). These results are similar in all four countries: the Federation of Bosnia and Herzegovina (4.21), Croatia (3.84), Serbia (3.82) and Slovenia (3.86). As expected, the non-parametric Kruskal-Wallis test shows no statistically significant differences between four countries for all three factors.

\subsection{Stakeholders' Involvement in the PES Schemes}

The largest proportion of respondents believe that public authorities should be involved in PES programs both as buyers and as regulators (63.6\% of all respondents), while for $16.7 \%$ of all respondents, public authorities should be involved only as regulators and for $14.4 \%$, only as buyers. The remaining $5.3 \%$ of all respondents emphasize the management of PES schemes without any intervention from the public sector.

An analysis of the data by country shows that respondents from the Federation of Bosnia and Herzegovina emphasize the role of public authorities as buyers and regulators more $(79.3 \%)$ than respondents from the other three countries $(50.0 \%$ of respondents in Croatia, $62.1 \%$ in Serbia, $66.7 \%$ in Slovenia). Conversely, $20.7 \%$ of respondents in Serbia would like to see more public sector involvement in PES schemes, but only as buyers. In the other countries, respondents would like to see this type of participation somewhat less (6.9\% in the Federation of Bosnia and Herzegovina, $18.4 \%$ in Croatia, $11.1 \%$ in Slovenia). Meanwhile, $23.7 \%$ of respondents from Croatia want the public sector to limit itself to the role of a regulatory authority $(13.8 \%$ in the Federation of Bosnia and Herzegovina, $10.3 \%$ in Servia, $16.7 \%$ in Slovenia). However, the chi-square $\left(\chi^{2}\right)$ test shows no statistically significant differences between the four countries $(\alpha=0.01, p=0.433)$.

Regarding the involvement of stakeholders in the PES schemes, the results show that for the majority of respondents, the following stakeholders should be involved at the level 
of collaboration: individual forest owners (29.2\% of all respondents), fishing associations $(40.8 \%)$, farmers' associations (39.2\%) and tourism associations (31.0\%). Conversely, according to the respondents, individual farmers should be informed (33.6\% of all respondents), while intermediaries (39.2\%), environmental NGOs $(34.4 \%)$ and citizens $(28.4 \%)$ should be consulted.

The results show that there are interesting differences between countries in terms of the level of involvement of different stakeholders. Respondents from Slovenia are the ones who consider a higher level of involvement of all stakeholders in PES schemes as a key element for their success. For Slovenian respondents, five groups of stakeholders (individual forest owners, farmers, fishing and tourism associations, citizens) should be involved through a collaboration and three groups of stakeholders (individual farmers, intermediaries, environmental NGOs) should be consulted. On the other hand, a high percentage of respondents from the Federation of Bosnia and Herzegovina (31.8\%) and Croatia (34.5\%) value involving citizens at the level of co-decision, while Serbian respondents only want to inform citizens (42.9\%). Respondents from Croatia, Serbia and Slovenia believe that tourism associations should be involved at the level of collaboration $(31.6 \%, 32.1 \%$ and $38.9 \%$, respectively), while respondents from the Federation of Bosnia and Herzegovina believe that these associations should only be informed.

\section{Discussion}

Although the legal framework in all countries studied recognizes the importance of forests' WES and the need for their financing, the payments schemes (PES) that exist in the forest sectors of three of four countries studied [45] have not been recognized as such $[26,28]$. Slovenia is the only country that has decided that the state should take the entire burden of financing natural resources management. The other three countries (the Federation of Bosnia and Herzegovina, Croatia and Serbia) are implementing financing schemes in forestry as pure PES and in water management as PES such as payments schemes for WES [26]. Those schemes have in common that they are influenced by states through command and control governance systems, that they lack the voluntary aspect and that there is a large intermediary distance between the providers of WES and the payers [26]. The intermediary distance shows the extent to which payers understand what they are paying for and to whom and, on the other hand, providers' understanding of their obligations to provide ES. This also shows the weak role of stakeholders outside the main sectors (forestry and water management) in the development of the PES schemes, as their attitudes and opinions have not been recognized as important enough to be included in the discussion, cooperation or decision making. The greater the intermediary distance, the weaker role of stakeholders, which is one of the main obstacles for the development of PES, along with the strong role of the state and cultural or societal attitude toward payments schemes $[26,46]$.

The stakeholders discussed in this paper are evenly distributed among selected countries, with most (57.3\%) coming from the forest sector but also from different groups of stakeholders (forest managers, forest administration, policy makers, decision makers and research and education). A similar structure of stakeholders was found in other related sectors such as water management, nature protection, economics, biology, geography and civil engineering, although they were not evenly represented. The prevalence of forestry stakeholders $(70.0 \%)$ reflects the valuation of forests' WES by recognizing the provisioning forests' WES as the most important also in the case of the Federation of Bosnia and Herzegovina.

The combined results for all four countries show that regulating services rank first in importance, confirming their importance for the sample of stakeholders, followed by provisioning, supporting, and cultural services, which are the least important. Some other studies $[19,47]$ support our findings. Individually, the highest scores are given to erosion reduction (Federation of Bosnia and Herzegovina, Croatia and Slovenia), and habitats provision (Serbia), with no significant differences between countries, what is in line with 
the similar situations experienced by the stakeholders in respective countries [48]. The weak position of cultural ES is also reported by Báliková et al. [19] which, with our findings, contrasts many other studies that often highlight ES [35,49], recognizing them as most important $[50,51]$. However, our results stem from the main objective of our study, which was to investigate the sectors that have the greatest impact on forestry WES (forestry and water management) intentionally excluding citizens and other user groups.

Significant differences were shown in the reduction of flood risk between the countries studied, with Slovenia's score being significantly lower than the other three countries. This can be explain by the influence of the devastating floods that caused severe damage to nature, infrastructure and houses in 2014 [52] and took many human lives in the Federation of Bosnia and Herzegovina, Croatia and Serbia, while Slovenia was affected in a much milder way.

Our results show a possible increase in trade-offs between ES for forest management activities and, with the exception of the Federation of Bosnia and Herzegovina, for afforestation/reforestation activities, which, as forestry activities, often promote provisioning ES. These results are consistent with Báliková et al. [19] and other studies pointing out forest management practice as focused on provisioning services and mitigate flow of other ecosystem services $[6,12,53]$. Some studies reported negative effects of the forest management practices depending on their intensity, especially concerning woody residue removal and clear-cutting, which can influence surface runoff water infiltration, flood risk and the quality of drinking water [54].

In terms of implementation, PES has been shown to be more effective than the "command and control" tool for protecting and providing WES. However, the "command and control" tools also have merits, especially where the state plays a strong role, as in the case of the studied countries. Command and control instruments are based on regulations that set environmental and emission targets and impose penalties for non-compliance with these standards [31]. In contrast, market-based instruments are based on price values or other economic values that can induce actors to reduce pollution or improve natural resource management [32]. Other studies examining the effectiveness of PES conclude that design is one of the most important influencing factors. PES programs differ in the type and level of ES demand, the source of payment, the mode and amount of payment, the type of activity paid for and the way performance is measured [23,36]. Characteristics such as the involvement of intermediaries and state actors, the length of the contract, the co-benefits, the voluntary nature of entering into a PES agreement and the design of PES schemes are considered particularly important for the success of PES schemes [55]. PES systems work best when services are visible, beneficiaries are well organized and users are well structured and have clear and secure ownership rights [56]. In most cases, a national PES policy would make it easier to initiate such market-oriented approaches to improve WES provision and motivate conservation effort than other schemes [33,57]. PES schemes, to be successful, need a very robust marketing and communication approach involving both key stakeholders and key political/institutional actors. Another factor found in the literature is the so-called "payment-culture" as part of the national or local culture [24,58]. It could help in overcoming of the general feeling that we pay many environmental taxes and already have many financial instruments at our disposal to deliver WES [28]. In that study, the PES was perceived as just one burden more on the back of taxpayers, mostly because it was imposed as obligatory and the prescribed rate was a purely political decision, which in combination with lack of transparency in the distribution of collected funds, make this payment to be consider as too high and not necessary [28,32].

In this respect, stakeholders' involvement is important and can help in both the design and implementation of PES. The main characteristics of the four levels of participation that we investigated are an increasing power in the hands of stakeholders and a simultaneous decrease in the number of stakeholders involved. According to Herwig [59] and Bréthaut [38], information does not mean that stakeholders are actively involved in the decision-making process but rather that decision makers want to inform them about what 
decision could be implemented. In consultation, stakeholders provide information, needs and interests to the decision makers, but they do not necessarily influence the implementation of the decision. In collaboration/deliberation, interests and arguments are considered and integrated into the decision-making process, while in co-decision/co-production, stakeholders actively participate in the decision-making process-from the definition of alternatives to the implementation of final decisions. However, an increased level of involvement may lead to a reduction in the number of stakeholders involved due to the necessary expenditure of tangible and nontangible resources.

Our results show a good uptake of the involvement of different stakeholders, with none of the proposed groups being omitted. The most important involvement in codecision reveille different situation in the Federation of Bosnia and Herzegovina, where individual forest owners and citizens were considered as the most welcomed. In the other three countries, that place belongs to different associations representing stakeholders (farmers, forest owners). For the second level of involvement, collaboration, again, the associations of stakeholders were recognized as welcomed to the process in Croatia, Serbia and Slovenia. In the Federation of Bosnia and Herzegovina, that role should be given to intermediaries and NGOs. This can be explained with the huge number of small private forest owners in those countries [27] and with the recent development in establishing of private forest owners' associations, which then can be more effectively involved in the process than individual forest owners. The different situation for the Federation of Bosnia and Herzegovina can be explained by its complicated administrative and political structure, which can omit successful representation of private forest owners by associations in the decision-making process [31]. Other studies emphasized role of stakeholder' participation in enhancing the quality of environmental decision-making processes [59-61]. This gives hope that in the future, different groups of stakeholders will be involved in decision-making and that this will be more of the norm in the development of PES in the studied countries.

\section{Conclusions}

In analysing stakeholder opinions on WES, we focused on opinions from two leading sectors, forestry and water management, to explore their perception of WES importance, the effectiveness of PES schemes and the needed involvement of other stakeholders in the decision-making process. In addition, we compared results across the four selected countries.

Concerning the importance of WES, we found a high level of agreement among the stakeholders, which prevalently placed regulating services in first place and provisioning services in second. A small but not statistically significant difference is shown for the Federation of Bosnia and Herzegovina, as they placed provisioning service in first and regulating in second place. Those results reflect a similar situation in all countries and prevailing representation of foresters in the sample, as they easily recognized those services as the most important.

Opinions on trade-offs between ES slightly differ among countries but, again, not statistically significant. Most of the respondents think that forest management activities can lead to potential trade-offs, where those from the Federation of Bosnia and Herzegovina give them a stronger position than those from other countries which recognized almost the same potential in afforestation/reforestation activities. Reasons for which we see in the majority of foresters among respondents from the Federation of Bosnia and Herzegovina.

When we looked at the effectiveness of PES in comparison with "command and control" systems, we also found a high level of agreement among the respondents recognizing PES as more efficient. Those findings were explained with the strong role of the state in all studied countries, where, when PES scheme exists, the voluntary principle does not. This was emphasized with weak transparency in the distribution of those funds, for which improvement can open opportunity window for the development of new instruments.

Strong state roles in both sectors do not leave much space for private initiatives in PES development, and together with the low level of involvement of other stakeholder groups, this represents obstacles to the development of new instruments. We found that 
most of respondents are not aware of existent PES schemes in their countries, although they exist [26]. This can be explained by the different definitions and names of the schemes of which some have been active for more than 20 years. In some of the existing schemes, forest WES are not defined, and ES usually are not structured to reflect any of global definition.

However, PES is seen as a promising mechanism to increase the supply and compensate the cost of hydrological services provision, which is important in the absence of an appropriate legal framework for its financing [61].

We found that respondents in all countries recognize the importance of several key aspects related to PES implementation, such as shared values on ES among societal actors, the incorporation of local knowledge into decision making and multi-level governance. In addition, they seem to be very open and positive to the involvement of other stakeholder groups in the decision-making process, which could alleviate existing obstacles to the development of new PES schemes.

It is very important to get new schemes right by providing structure and positive environment for negotiation and at the end to ensure that all payments are actually returned and used for investment in water-forest restoration and thus for the provision of WES.

This study analysed the opinions of the main group of stakeholders from both sectors, which actually represent decision makers in respect of forest and water management. To understand the needed structure and environment for the development of new PES schemes in each country, the opinions of all other stakeholder groups should be included into the investigation, especially citizens as users of WES.

To conclude, there is a high level of agreement among respondents' opinions about most of the WES aspects, in four studied countries. Both sectors shared attitudes towards importance of WES on the role of public authorities and are positive towards the involvement of other stakeholder groups in the decision-making process, which we see as good ground for creating new PES schemes.

Concerning the chosen methodology, this study used an online survey, which was listbased according to previously conducted stakeholder analysis and has a non-probability sample of selected stakeholders from forestry and water management sectors in four countries. The proposed method has advantages in simplicity, transparency and timesaving in data gathering, and conversely, it can be disadvantageous when a substantial sample of respondents was not reached.

Author Contributions: Conceptualization, K.B., A.P. and D.V.; data curation, D.V., M.A., K.P., S.S., S.P. and Š.P.M.; formal analysis, K.B., A.P., S.S., M.A., K.P. and Š.P.M.; investigation, M.A., S.S., D.V., K.P. and Š.P.M.; methodology, K.B. and A.P.; validation, K.B., A.P., S.K.O., M.A., K.P., Š.P.M. and S.P.; visualization, K.B., A.P., S.S. and D.V.; writing—original draft, D.V., K.B., A.P. and S.K.O.; writing—review and editing, K.B., D.V., A.P., S.K.O., M.A., Š.P.M., S.S. and K.P. All authors have read and agreed to the published version of the manuscript.

Funding: This research was partially funded by COST Action CA15206-PESFOR-W (Forests for Water), and from national funds involved countries.

Institutional Review Board Statement: The study was conducted according to the guidelines of the Declaration of Helsinki, and approved by the Institutional Ethics Committee CROATIAN FOREST RESEARCH INSTITUTE (640-01/2021-01/25, 238/12-20-01-2021-1, 29 June 2021).

Informed Consent Statement: Informed consent was obtained from all subjects involved in the study.

Data Availability Statement: The data presented in this study are available on request from the corresponding author. The data are not publicly available due to privacy restrictions.

Acknowledgments: The authors wish to thank all the additional experts who took part in this research and made it possible.

Conflicts of Interest: The authors declare no conflict of interest. 


\section{References}

1. Blahna, D.J.; Asah, S.T.; Deal, R.L. An ecosystem services framework. In People, Forests, and Change: Lessons from the Pacific Northwest; Olson, D.H., Van Horne, B., Eds.; Islan Press: Washington, DC, USA, 2017; pp. 62-75. ISBN 9781610917681.

2. Archer, E.; Bishop, K.; Gebrehiwot, S.G.; Haywood, L.K.; Robson, J.P. Governance Options for Addressing Changing Forest-Water Relations. In Forest and Water on a Changing Planet: Vulnerability, Adaptation and Governance Opportunities; IUFRO: Vienna, Austria, 2018; pp. 147-169. ISBN 978-3-902762-95-5.

3. Ellison, D.; Morris, C.E.; Locatelli, B.; Sheil, D.; Cohen, J.; Murdiyarso, D.; Gutierrez, V.; van Noordwijk, M.; Creed, I.F.; Pokorny, J.; et al. Trees, forests and water: Cool insights for a hot world. Glob. Environ. Chang. 2017, 43, 51-61. [CrossRef]

4. Leonardi, A. Characterizing Governance and Benefits of Payments for Watershed services In Europe; University of Padua: Padua, Italy, 2015.

5. Valatin, G.; Abildtrup, J.; Accastello, C.; Al-Tawaha, A.R.; Andreucci, M.-B.; Atanasova, S.; Avdibegović, M.; Baksic, N.; Banasik, K.; Barquin, J.; et al. PESFOR-W: Improving the design and environmental effectiveness of woodlands for water Payments for Ecosystem Services. Res. Ideas Outcomes 2017, 3, e13828. [CrossRef]

6. Fao, U. Forests and Water-Valuation and Payments for Forest Ecosystem Services; UN: Geneva, Switzerland, 2007; Volume 58, ISBN 9789211171754.

7. Claassen, M. Forest and Water on a Changing Planet. In Vulnerability, Adaptation and Governance Opportunities; Creed, I.F., van Noordwijk, M., Eds.; IUFRO: Vienna, Austria, 2018; Volume 38, p. 192. ISBN 3901347240.

8. Reid, V.W.; Mooney, H.A.; Cropper, A.; Capistrano, D.; Carpenter, R.S.; Chopra, K. Millennium Ecosystem Assessment. Ecosystem and Human Well-Being-Synthesis; Island Press: Washington, DC, USA, 2005; ISBN 1597260401.

9. Travel Cost Method (TCM). Available online: www.ecosystemvaluation.org/travel_costs.htm (accessed on 10 June 2021).

10. Czúcz, B.; Arany, I.; Potschin-Young, M.; Bereczki, K.; Kertész, M.; Kiss, M.; Aszalós, R.; Haines-Young, R. Where concepts meet the real world: A systematic review of ecosystem service indicators and their classification using CICES. Ecosyst. Serv. 2018, 29, 145-157. [CrossRef]

11. Wunder, S.; Thorsen, B.J. Quantifying water externalitites from forests. In The Provision of Forest Ecosystem Services; Vol. 1. Quantifying and Valuing Non-Market Ecosystem, Services; Thoresen, B.J., Mavsar, R., Tyrväinen, L., Prokofieva, I., Stenger, A., Eds.; Eureopean Forest Institute: Joensuu, Finland, 2014; pp. 21-25.

12. Garcia-Chevesich, P.A.; Neary, D.G.; Scott, D.F.; Benyon, T.R. Forest Management and the Impact on Water Resources: A Review of 13 Countries; VIII; IHP: Paris, France, 2017; ISBN 1047-3203.

13. Creed, I.F.; Weber, M.; Accatino, F.; Kreutzweiser, D.P. Managing Forests for Water in the Anthropocene-The Best Kept Secret Services of Forest Ecosystems. Forests 2016, 7, 60. [CrossRef]

14. Springgay, E.; Dalton, J.; Samuelson, I.; Bernard, A.; Buck, A.; Cassin, J.; Matthews, N.; Mathews, J.; Tengberg, A.; Bourgeois, J.; et al. Championing the Forest-Water Nexus-Report on the Meeting of Key Forest and Water Stakeholders; Stockholm International Water Institute: Stockholm, Sweden, 2018.

15. Hamilton, L.S.; Hamilton, L.S. Forest and Water; Hamilton, L.S., Dudley, N., Greminger, G., Hassan, N., Lamb, D., Stolton, S., Tognetti, S., Eds.; FAO Forest; FAO: Roma, Italy, 2005; ISBN 9789251060902.

16. Paletto, A.; Báliková, K.; De Meo, I. Opinions towards the water-related Payments for Ecosystem Services (PES) schemes: The stakeholders' point of view. Water Environ. J. 2021, 35, 1051-1062. [CrossRef]

17. Eriksson, M.; Samuelson, L.; Jägrud, L.; Mattsson, E.; Celander, T.; Malmer, A.; Bengtsson, K.; Johansson, O.; Schaaf, N.; Svending, O.; et al. Water, Forests, People: The Swedish Experience in Building Resilient Landscapes. Environ. Manag. 2018, 62, 45-57. [CrossRef]

18. Reed, M.S.; Allen, K.; Dougill, A.J.; Evans, K.L.; Kenter, J.O.; Hoy, J.; McNab, D.; Stead, S.M.; Twyman, C.; Scott, A.S.; et al. A place-based approach to payments for ecosystem services. Glob. Environ. Chang. 2017, 43, 92-106. [CrossRef]

19. Báliková, K.; Červená, T.; De Meo, I.; De Vreese, R.; Deniz, T.; El Mokaddem, A.; Kayacan, B.; Larabi, F.; Lībiete, Z.; Lyubenova, M.; et al. How Do Stakeholders Working on the Forest-Water Nexus Perceive Payments for Ecosystem Services? Forests 2019, 11, 12. [CrossRef]

20. Mäntymaa, E.; Juutinen, A.; Tyrväinen, L.; Karhu, J.; Kurttila, M. Participation and compensation claims in voluntary forest landscape conservation: The case of the Ruka-Kuusamo tourism area, Finland. J. For. Econ. 2018, 33, 14-24. [CrossRef]

21. Smith, S.; Rowcroft, P.; Rogers, H.; Quick, T.; Eves, C.; White, C.; Everard, M.; Couldrick, L.; Reed, M. Payments for Ecosystem Services: A Best Practice Guide; DEFRA: London, UK, 2013.

22. Wunder, S. Revisiting the concept of payments for environmental services. Ecol. Econ. 2015, 117, 234-243. [CrossRef]

23. Engel, S.; Pagiola, S.; Wunder, S. Designing payments for environmental services in theory and practice: An overview of the issues. Ecol. Econ. 2008, 65, 663-674. [CrossRef]

24. Bösch, M.; Elsasser, P.; Wunder, S. Why do payments for watershed services emerge? A cross-country analysis of adoption contexts. World Dev. 2019, 119, 111-119. [CrossRef]

25. Diswandi, D. New Approach on Payment for Environmental Services Literature: Development and Challenges. In Proceedings of the Western Australia Branch 1st Biannual Conference, Australian Agricultural and Resource Economics Society, Perth, Australia, 12-14 February 2015; pp. 1-14.

26. Vuletić, D.; Ostoić, S.K.; Keča, L.; Avdibegović, M.; Potočki, K.; Posavec, S.; Marković, A.; Malovrh, Š.P. Water-related payment schemes for forest ecosystem services in selected Southeast European (SEE) countries. Forests 2020, 11, 654. [CrossRef] 
27. Živojinović, I.; Weiss, G.; Lidestav, G.; Feliciano, D.; Hujala, T.; Dobšinska, Z.; Lawrence, A.; Nybakk, E.; Quiroga, S.; Schraml, U. Ownership Change in Europe; European Forest Institute Central-East and South-East European Regional Office (EFICEEC-EFISEE): Vienna, Austria, 2015; ISBN 9783900932268.

28. Vuletić, D.; Posavec, S.; Krajter, S.; Paladinić, E. Payments for Environmental Services (PES) in Croatia-Public and Professional Perception and Needs for Adaptation. South-East Eur. For. 2010, 1, 61-66. [CrossRef]

29. Sekulić, G. Analysis of Pes Needs and Feasibility in Serbia; Work. Together to Inspire Sustain. Solut; WWF Danube-Carpathian programme: Vienna, Austria, 2012.

30. Delić, S.; Vuletić, D.; Zadnik Strin, L.; Avdibegović, M.; Bečirović, D.; Mutabdžija, S.; Marić, B.; Pezdevšek Malovrh, Š. Models of Finnancing Forest Ecosystem Services in the Federation of Bosnia and Herzegovina, Croatia and Slovenia. In Proceedings of the Socio-Economic Analyses of Sustainable Forest Management; Prague, Czech Republic, 15-17 May 2013; Ludek, S., Dudik, R., Hrib, M., Eds.; IUFRO: Prague, Czech Republic; p. 165.

31. Sector, Economic Value of Forest, and Tree Cover Change. FAO The Forest Sector in Bosnia and Herzegovina; FAO: Roma, Italy, 2015; p. 155.

32. Keca, L.; Markovic, A. Payments for ecosystem services and stakeholder's perspectives in Serbia. J. Agric. For. 2019, 65, 89-97. [CrossRef]

33. Rai, R.; Shyamsundar, P.; Bhatta, L. Designing a Payment for Ecosystem Services Scheme for the Sardukhola Watershed in Nepal; Work. Pap.; South Asian Network for Development and Environmental Economics (SANDEE): Kathmandu, Nepal, 2016.

34. Kagombe, J.K. Payment for environmental services: Status and opportunities in Kenya. J. Resour. Dev. Manag. 2018, 40, 1-13.

35. De Meo, I.; Cantiani, M.G.; Ferretti, F.; Paletto, A. Qualitative Assessment of Forest Ecosystem Services: The Stakeholders' Point of View in Support of Landscape Planning. Forests 2018, 9, 465. [CrossRef]

36. Berger-Garcia, M.A. Effectiveness of Payment for Environmental Services Programs in Mexico. Ph.D. Theses, Clemson University, Clemson, SC, USA, 2015.

37. Börner, J.; Baylis, K.; Corbera, E.; Ezzine-De-Blas, D.; Honey-Rosés, J.; Persson, U.M.; Wunder, S. The Effectiveness of Payments for Environmental Services. World Dev. 2017, 96, 359-374. [CrossRef]

38. Varvasovszky, Z.; Bruga, R. How to do ( or not to do ) ... A stakeholder analysis. Health Policy Plan. 2000, 15, 338-345. [CrossRef]

39. UNECE Forests and Water; 1827416 E.; UN: Geneva, Switerland, 2018; Volume 58, ISBN 9789211171754.

40. Pettenella, D.; Vidale, E.; Gatto, P.; Secco, L. Paying for water-related forest services: A survey on Italian payment mechanisms. iForest-Biogeosciences For. 2012, 5, 210-215. [CrossRef]

41. Muradian, R.; Corbera, E.; Pascual, U.; Kosoy, N.; May, P. Reconciling theory and practice: An alternative conceptual framework for understanding payments for environmental services. Ecol. Econ. 2010, 69, 1202-1208. [CrossRef]

42. Tacconi, L. Redefining payments for environmental services. Ecol. Econ. 2012, 73, 29-36. [CrossRef]

43. Saaty, R.W. The analytic hierarchy process-what it is and how it is used. Math. Model. 1987, 9, 161-176. [CrossRef]

44. Alonso, J.A.; Lamata, T. Consistency in the analytic hierarchy process: A new approach. Int. J. Uncertain. Fuzziness Knowl. Based Syst. 2006, 14, 445-459. [CrossRef]

45. Wunder, S. Payments for environmental services: Some nuts and bolts. CIFOR Ocas. Pap. 2005, $42,32$.

46. Wunder, S.; Brouwer, R.; Engel, S.; Ezzine-De-Blas, D.; Muradian, R.; Pascual, U.; Pinto, R. From principles to practice in paying for nature's services. Nat. Sustain. 2018, 1, 145-150. [CrossRef]

47. Calder, I.R. Forests and Hydrological Services: Reconciling public and science perceptions. Land Use Water Resour. Res. 2002, 2, 1-12.

48. EC Commission Opinion on Bosnia and Herzegovia's application for membership of the European Union; European Commission: Brussel, Belgium, 2019.

49. De Vreese, R.; Van Herzele, A.; Dendoncker, N.; Fontaine, C.M.; Leys, M. Are stakeholders' social representations of nature and landscape compatible with the ecosystem service concept? Ecosyst. Serv. 2019, 37, 100911. [CrossRef]

50. Iceland, C.; Hanson, C.; Lewis, C. Dentifying Important Ecosystem Goods and Services in PugetSound; World Resources Institute: Washington, DC, USA, 2008.

51. Torralba, M.; Lovric, M.; Roux, J.-L.; Budniok, M.-A.; Mulier, A.-S.; Winkel, G.; Plieninger, T. Examining the relevance of cultural ecosystem services in forest management in Europe. Ecol. Soc. 2020, 25, 25. [CrossRef]

52. Merdić, E.; Sudarić Bogojević, M.; Vignjević, G.; Turić, N.; Zahirović, Ž.; Vrućina, I. After flood-Croatia, 2014. In Proceedings of the European Mosquito Control Association; 7th EMCA Workshop 2015, Final Programme/Ruben Bueno Mari (ur.), Valencia, Spain, 23-26 February 2015; p. 88.

53. Biber, P.; Borges, J.G.; Moshammer, R.; Barreiro, S.; Botequim, B.; Brodrechtová, Y.; Brukas, V.; Chirici, G.; Cordero-Debets, R.; Corrigan, E.; et al. How Sensitive Are Ecosystem Services in European Forest Landscapes to Silvicultural Treatment? Forests 2015, 6, 1666-1695. [CrossRef]

54. Deniz, T.; Paletto, A. Effects of bioenergy production on environmental sustainability: A preliminary study based on expert opinions in Italy and Turkey. J. For. Res. 2018, 29, 1611-1626. [CrossRef]

55. Meyer, C. Institutional Aspects of Governmental Payments for Ecosystem Services. Ph.D. Thesis, Fakultät der HumboldtUniverisät zu Berlin, Berlin, Germany, 2015.

56. Mayrand, K.; Paquin, M. Payments for environmental services: A survey and assessment of current schemes. Unisfera Int. Centre. Montr. Canada 2004, 1-52. 
57. Loft, L.; Gehrig, S.; Le, D.N.; Rommel, J. Effectiveness and equity of Payments for Ecosystem Services: Real-effort experiments with Vietnamese land users. Land Use Policy 2019, 86, 218-228. [CrossRef]

58. Wunder, S. When payments for environmental services will work for conservation. Conserv. Lett. 2013, 6, 230-237. [CrossRef]

59. Herwig, U. Public Participation in the Establishment and Management of the Natura 2000 Network: Legal Framework and Administrative Practices in Selected Member States; UFZ Discussion Papers: Leipzig, Germany, 2008; Volume 1.

60. Schomers, S.; Matzdorf, B. Payments for ecosystem services: A review and comparison of developing and industrialized countries. Ecosyst. Serv. 2013, 6, 16-30. [CrossRef]

61. Schomers, S.; Matzdorf, B.; Meyer, C.; Sattler, C. How Local Intermediaries Improve the Effectiveness of Public Payment for Ecosystem Services Programs: The Role of Networks and Agri-Environmental Assistance. Sustainability 2015, 7, 13856-13886. [CrossRef] 